\title{
The transformation of companies from the standpoint of participation rights: The case of Slovenia*
}

\author{
Boštjan Zalar ${ }^{* *}$
}

Analysis of the legislation from the transitional period shows that, despite some uncertainties regarding the formal state of the protection of the rights of industrial democracy, this aspect of democratic development together with the right to join trade-unions seems to have enough guarantees for an adequate standard of protection in practice. This is not the case, however, when speaking of the rights of economic democracy, as these were only temporarily institutionalised. Although the constitutional concept of human rights in Slovenia is based on the triple principle of freedom, equality and justice, the author finds the exclusion of the participation rights of economic democracy from the system of legally enforceable rights to be the major deficiency in the legislature on participation rights.

Eine Analyse der Gesetzgebung während der Transformationsperiode läßt vermuten, daß (trotz einiger Unsicherheiten ihres formalen Status) der Schutz der Mitbestimmungsrechte im Zusammenhang mit dem Recht zur Bildung von Gewerkschaften auch in der Praxis ausreichend sei. Dies ist jedoch nicht der Fall, da sich Mitbestimmungsrechte gerade erst herausbilden und nur teilweise institutionalisiert sind. Obwohl das Grundkonzept der Menschenrechte in Slowenien auf den Prinzipien der Freiheit, Gleichheit und Gerechtigkeit basiert, stellt der Autor den Ausschluß des Rechtes auf Partizipation im ökonomischen Bereich aus dem Rechtssystem fest. Dies kennzeichnet den wesentlichen Unterschied in der Gesetzgebung bezüglich der Partizipationsrechte in Slowenien.

Manuscript received: 2.6.97, accepted: 21.10.97

** Boštjan Zalar, born 1965, Doctoral candidate and research fellow, University of Ljubljana, Faculty of Social Sciences; Main research topics: privatization from the human rights law point of view.

Mail address: Faculty of Social Sciences, Institut of Social Sciences, Center for Evaluations and Strategic Studies Kardeljeva pl. 1, 1000 Ljubljana, Slovenia

Tel.: +386-61-1683118 


\section{Introduction}

The model of (ownership) transformation of commercial companies in the Republic of Slovenia was adopted on December 5th, 1992 with the Law on Transformation of Company Ownership (herein after LTCO). It shows some similarities to the models in Central and Eastern Europe. The following procedures are most typical in this regard:

- the sale of shares at reduced prices (50\% discount) to employees (including managers);

- the free distribution of vouchers among the citizens;

- the allocation of $40 \%$ of the shares of each company to the pension, compensation and development funds;

- public sale of company shares (LTCO 1992).

On the basis of this law, the citizens of Slovenia and employees should become owners of a given amount of company shares or of some assets that were previously socially owned. ${ }^{1}$

However, to understand the importance of the LTCO in the transformation process of companies in Slovenia from the participation rights point of view, it is necessary to establish a thesis of interdependency and indivisibility of the rights of industrial, economic and trade union democracy.

The right of trade union democracy means the right for everyone to form and join trade unions for the protection of his/her interests as defined in Art. 22 of the International Covenant on Civil and Political Rights (1988) or in Art. 11 of the Convention for the Protection of Human Rights and Fundamental Freedoms (1995).

The rights of industrial democracy mentioned in this paper are related to all kinds of existing participation models in Europe, which regulate the involvement of employees in the decision making processes and supervision at all levels of the company, for example: the right to self-regulation of the working environment, the right to be informed about particular decisions or to be consulted before implementation of decisions in certain defined cases, or even the right to veto decisions which have important social consequences for employees.

The rights of economic democracy have to be understood as the employee right to share profits together with managers and owners and (or) the right to

1 Before the adoption of the LTCO the capital of companies was legally considered as social property. It was neither in the ownership of employees nor in that of the companies as legal entities. The prevailing supposition was that it was in the ownership of all citizens of the Socialist Federal Republic of Yugoslavia. 
employee share-ownership (Proposal for a Council Recommendation concerning the promotion of employee participation in profits and enterprise results including equity participation 1991). These two rights might also be considered as the means for the gradual realisation and protection of the right to fair remuneration, which is, to an extent, already taken into account in Art. 4 of the European Social Charter (1992).

I will use the notion "right" in relation to economic, industrial and trade union democracy, because this paper is based on the idea that political, civil, economic, social and cultural rights should be more integrated and treated as interdependent. This was actually the idea at the very beginning of the United Nations human rights charters (Universal Declaration of Human Rights 1988) and it is still on the agenda for some international policy makers (Vienna Declaration 1993), UN officials (Lasso 1994/95) and commentators as well (Sudre 1990; K?nnemann 1995).

Since this paper will concentrate on the problems of the transformation of companies in relation to the legislation on employee participation rights, it is necessary that the entire legal framework regulating this field is examined.

But, in order to gain a better understanding of the approaches to privatisation, we need to go back in time (before the adoption of the new Constitution) when the first laws regulating the status and ownership transformation of companies were passed in Slovenia.

\section{The legal framework for the transformation of companies before the adoption of the new constitution}

The transformation of the status of Slovenian companies had already begun in January 1989. It occured at the time of the adoption of the Law on Companies (herein after LC), but still within the legal order of the Socialist Federal Republic of Yugoslavia.

The major scope of the LC was to initiate the transformation process of company status and the gradual adaptation to proven forms of the developed market economy. According to this law, some companies were transformed from the so called social companies into joint-stock companies and into limited liability companies. The capital of these companies was legally still considered as social property, but it had formally been divided into shares.

According to similar laws in Western European countries, the LC should regulate all aspects of commercial companies from the question of the company title, registered office, business literature and annual reports, to the definitions of different types of companies and their bodies, including mergers, acquisitions and transformation of companies. Instead of this, the LC consisted of only about 200 articles. From an industrial democracy point of view, it is interesting, that 
the LC has completely overruled the old industrial democracy legislation and has simply introduced nothing in its place. So, the LC initiated a system which was the direct converse to previous legislation in Yugoslavia. Legislation until then, as a response to capitalism, was based on the principle of the complete domination of labour over capital, by binding all participation rights (including management) to labour and thereby formally abolishing capital. ${ }^{2}$

Because the LC has had absolutely no implication of the rights of industrial democracy being a civilisation standard within the process of democratisation and humanisation of work, this law has also failed in the approach to the proposed legal standards of the European Union in this field (Amended proposal for a Fifth Directive founded on Article 54 (3) (g) of the EEC 1983; Proposal for a Council Directive complementing the Statute for a European company with regard to the involvement of employees in the European company 1989).

The first law supporting economic democracy in this transitional period was the Law on Social Capital (December 1989), which ceased the prohibition on the disposal ("ius disponendi") of social assets. According to this law, companies were able to convert their debt into stock and to sell socially-owned assets to Yugoslavian and foreign legal entities. The amendment to this law in August 1990 gave companies the possibility to issue employee shares for the purpose of internal buy-outs or in order to raise additional equity capital.

The period from 1989 to 1992, when these legal reforms were introduced, which transformed the system from socialist self-government into a system of private ownership, was characterised by a high degree of entropy. The situation in Slovenia compared to other Eastern and Central European countries was specific in so far as there was not only a transformation of the social and economic system, but also a process of forming a new, internationally acknowledged state. Numerous unexpected changes in the socio-economic and political field, as well as in the sphere of social values, have culminated into conflict with the Yugoslav People's Army during the brief war period. Due to the war in the Balkans, Slovenian companies had to find new markets in the more demanding Western markets or the remaining Central or Eastern European markets.

Under the circumstances it is impossible to isolate the concrete and direct consequences of the new laws on industrial, economic and trade union democracy. However, there is a sufficient evidence which suggests a general deterioration of employee rights during this period. The evidence is provided by

2 The exclusive right of labour to determine the fortunes of companies was amended in 1988 when the Constitution of SFRY was changed in order to also recognise the right of (socially owned) capital to play a legitimate role in the decision-making processes in companies and in economic system in general. 
the reports of three different institutions which were - each in its own way monitors over the protection of (not just) employee participation rights. ${ }^{3}$

The number of reports of violations which were received by these three institutions increased steadily. In 1992 the number of complaints to the Council for the Protection of Human Rights and Fundamental Freedoms was twice as high as in 1991, and from 1990 to 1991 the Labour Court had a $100 \%$ increase in cases.

The reports clearly show that the most arbitrary and massive violations (of all human rights) were made in the field of the protection of employee participation rights. Most disputes were in connection with the ceasing of employment within programmes of redundancies and transfer to other workplaces.

There were also numerous disputes and violations of collective agreements issues which broadly could be classified as violations of economic democracy.

These violations are:

- disrespect of the obligations from wage agreements of collective bargaining;

- controversies in connection with the classification into grades and salary bands;

- problems regarding the evaluation of work places and personal incomes;

- intolerable delays with the payment of salaries;

- illegal proceedings on the payment of money compensation in the case of unemployment or illness.

Concerning the field of industrial democracy, I can only point to some cases of restriction of the workers right to solve the disputes before neutral bodies in the company. The report of the Labour Court emphasised the standpoint that the management of some companies have handled disciplinary proceedings without authorisation. This is especially true in the case of companies which were transformed into limited liability companies.

Regarding the field of trade union democracy the reports make it clear that most problems were caused because procedures for the authorisation and naming of trade union representatives in companies were not defined in law. A special problem was the general trade union disorganisation in the sense that trade

3 These are three reports and a memorandum from the Council for the Protection of Human Rights and Fundamental Freedoms which was, as an institution of civil society, the predecessor of the present Ombudsman. A part from this, I have used reports from two state bodies, namely of the Social Attorney of Self-Management who was a general attorney of socially-owned capital from the beginning of the socialist system and a report from the Labour Court - specialized for cases falling under the legislation of labour. 
unions were not effective in protecting and representing employee rights and their interests.

During this period all three institutions have put pressure on the government and parliament to prepare as soon as possible a legislation which will:

- reorganise the special courts for labour and social disputes;

- set a framework for the organisation of trade unions;

- set a framework for employee participation rights;

- implement a network of inspectors of working conditions so that employee need not always seek help in court (Council for the Protection of Human Rights and Fundamental Freedoms 1991, 1992, 1993a, 1993b; Social Attorney of Self-Management 1992, 1993; Labour Court 1993).

The above described violations of employee participation rights were probably also caused by the fact that during the last 40 years in SFRY, the notion of "human rights" was linked essentially to labour law and employment. With the beginning of the economic reforms and a new wave of liberal values the old belief in labour rights has been undermined in legislature and even further in practice. Furthermore, the overburdened labour courts in fact represented a guarantee for the potential violators that they would not be appropriately sanctioned.

\section{The period after the adoption of the new constitution}

In order to understand the present legal status and protection of employee participation rights in the new Slovenian legislation on commercial companies, I need to explain three areas of legislation:

- the Constitution which provides the basic framework of human rights;

- the Law on Commercial Companies which among other things deals with the composition of bodies in commercial companies and the rights of shareholders;

- the Participation of Employees in the Management Act which most directly deals with the labour side in the sense of employee participation in decision making processes and supervision of business operations.

Each of these will be considered in turn. In the third part of the chapter 3, I will present the report regarding the level of the protection for employee participation rights during this period.

The status of employee right to shareholdership and profit-sharing will be discussed in a (separate) chapter 4. 


\subsection{The constitution of slovenia}

The Slovenian Parliament adopted a new Constitution in December 1991.

The constitutional concept of human rights in Slovenia differentiates between the basic political and civil rights on the one hand (II. Chapter of the Constitution), which are enforceable in court and have the so called "negative" status, and on the other hand the economic and social rights (III. Chapter of the Constitution), which have a "positive" status. ${ }^{4}$ According to the Commission for Constitutional Questions, which prepared the new Constitution, the economic and social rights are not adequately developed to guarantee an effective legal protection. If they were incorporated among the classic human rights, it would lower the level of protection guaranteed by law. The Commission for Constitutional Questions (1991) declared them as "programmatic" and "ideological", and understands them as an obligation of the state to establish the circumstances for their future legal protection. ${ }^{5}$ However, from the classical liberal doctrine point of view, this legal separation of civil and political rights from the economic and social rights in the Constitution of the Republic of Slovenia was not consistently followed. Namely, the right to health care and the right to social security were included among the classical liberal rights that are legally enforceable. However,

the problem is that the constitutional basis for the rights of industrial and trade union democracy - the right to participate in decision making processes and supervision of business operations, the right to join trade unions, together with the right to strike - has been also placed under Chapter III. of the Constitution, under the so called "programmatic" or "ideological" rights. ${ }^{6}$

4 We have thus adopted a concept which is also valid at the level of international law on human rights. On one side we have the International Covenant on Civil and Political Rights and on the other the International Covenant on Economic, Social and Cultural Rights (1988) where the Article 2. represents the foundation for the positive status of the rights from this covenant. At the level of the European human rights law the demarcation was set with the Convention for the Protection of Human Rights and Fundamental Freedoms and the European Social Charter.

5 Among these so called "programatic" rights the Constitution mentions the right to adequate housing, the right to work, the right to a healthy environment etc. (The Constitution of the Republic of Slovenia 1991).

6 The formal position of the right of trade union freedom in the Constitution of Slovenia is not in accordance with the regulation of this right in the Convention for the Protection of Human Rights and Fundamental Freedoms, where it has a negative status (1995: Article 11. and Art. 13.). 
The field of economic democracy in the Constitution is regulated merely by a classic provision ensuring the right to own property (Article 33, Chapter II.). With regard to Article 67. of the Constitution (Chapter III.), a special law should regulate the possible ways of acquiring possessions, also in order to ensure economic, social and ecological function of property.

In a case which was in no way related to the economic, industrial or trade-union democracy, the Constitutional Court of Slovenia gave an explanation for the differentiation between human rights from the second Chapter and human rights from the third Chapter of the Constitution. The Constitutional Court supported the argumentation for the legal differentiation between the civil and political rights on the one side and the economic, social and cultural rights on the other in the same way as it was defended by the Commission for Constitutional Questions Yet a concrete decision of the Constitutional Court shows a more appealing, and to my opinion, a more progressive (but separated) position of the Constitutional Judge M. Krivic. Judge Krivic expressed the idea that the Constitutional Court should recognise as a basic human rights, some other ones as well, for example one from international charters that are valid in Slovenian legislature (for example: from the Convention for the Protection of Human Rights and Fundamental Freedoms), or the rights which already are in the Constitution, but in Chapter III. instead of Chapter II. (The Constitutional Court 1992, 39/I, separate opinion of Judge Krivic).

I have the pleasure in establishing that judge Krivic's position had proved to be right. Nine months after the passing of this rigid decision of the Constitutional Court regarding the status of the rights from Chapter III. of the Constitution, the same institution accepted the decision, which recognised the negative status to the right of free economic initiative, otherwise being in Chapter III. (The Constitutional Court 1993, 18/II).

Other decisions of the Constitutional Court also strengthened the trend of transcending the paradigm of the disintegration and independence of rights from Chapter II of the Constitution with those rights from Chapter III of the Constitution. From the arguments of the Constitutional Court it may also be understood that the right to participate in the management of (non)commercial companies is recognised the status of enforceability (The Constitutional Court 1994: 86/III). The same applies for the right to strike (The Constitutional Court 1994: 38/III), as well as the right to freedom of association, operation and the formation of trade unions (The Constitutional Court 1994: 85/III).

The Constitutional court also gives equal legal protection to classical civil and political rights as well as to the provision of Chapter III of the Constitution, which regulates ownership rights (The Constitutional Court 1992: 35/I, 56/I; The Constitutional Court 1993: 52/II, 117/II, 121/II; The Constitutional Court 1994: 39/III, 50/III, 99/III). This provision (Article 67) stipulates that the law should regulate the acquisition and enjoyment of ownership rights in a manner 
ensuring its economic, social and ecological functions. It is also relevant that the Constitutional Court make reference to the general provision of Article 2 of the Constitution, which stipulates that Slovenia is a welfare state (The Constitutional Court 1992: 23/I; The Constitutional Court 1995: 147/IV, Vol. 2) and that the notion of welfare state actually represents the principle of justice (The Constitutional Court 1995: 42/IV, Vol. 1).

From the above-mentioned I may conclude that the Constitutional Court has not only mitigated, but to a significant degree corrected the initial legal separation of civil and political rights on the one side from economic, social and cultural rights on the other. This has clarified and strengthened the legal status of rights of industrial and trade union democracy as enforceable participation rights. One area that has remained insufficiently protected is the field of economic democracy rights. For this reason I have devoted a special section - Chapter 4 of this contribution - to the problem of economic democracy rights.

\subsection{The law on commercial companies and participation of employees in management act}

The Law on Commercial Companies (herein after LCC) was adopted in July 1993. It annulled a non-satisfactory regulation on the status of commercial companies, which was since January 1st, 1989 regulated by the LC. The solutions in the LCC were adjusted with reference to directives and recommendations of the European Union. The trends of the European legislation on corporations were considered, too, so that all conditions for the compatibility of the Slovenian economic system with the European Union jurisdiction were fulfilled.

However, in comparison to similar laws of other European countries it is considerably less detailed regarding the regulation of:

- cases of exclusive competence of the assembly of a corporation (opening of branch offices, mergers, sales and buying of real estate and other cases of risky business);

- rights of minority share-holders (nomination of a representative to the supervisory board; nomination of an expert for the inspection of business operations; dealing with accusations of negligence against a member of the executive or supervisory board);

- rights of privileged share-holders (the possibility of the shareholders to convene a special assembly of privileged shareholders at the issue of additional preferred shares and when distributing profit; the right to ask questions and make suggestions etc.).

The LCC does not regulate the participation rights of employees. This is the mission of the Participation of Employees in the Management Act (herein after PEMA), which explicitly deals with the issue of industrial democracy models 
and thus overcomes the negative inheritance of the 1989 LC. The PEMA is in accordance with the proposed documents of the European Union. The basic concept is that employee right to take an active part in business decisions at the highest company level are restricted in their right to information and consultation through employee representatives, which are, of course, not necessarily members of trade-unions. Regarding the decisions at company level that have important social consequences, the employee representatives have the right of veto. The right of supervision over the business operations is divided between capital owners and employees in the following way, that the employees in companies with more than 1000 employed hold at least one half of the seats of the supervisory board; elsewhere (where supervisory boards are installed) they hold at least one third of the seats on the supervisory board (PEMA 1993).

Such a legal approach to the regulation of industrial democracy is in my opinion the right way, but there are still some deficiencies. The first would be that the PEMA pays too little attention to the (self)regulation of the working environment. The right to participate in the regulation of the working environment should be guaranteed as a basic participation right in companies. It is substantially connected with the constitutional rights, for example the right to personal dignity and safety and the right to freedom of expression. The field of self-regulation of the working environment is not only connected with the notion of human rights, but also with the conception of competition. The legalisation of participation rights at the level of the workplace, as it was adopted in some Northern European countries, would establish the necessary basis for the development of various forms of democracy at the workplace, such as quality circles, autonomous working groups, etc. In American companies employee participation at the level of workplace was reached in a different way. Successful companies are aware that those who do a job know more about it than anybody else. Therefore, the employees are given more power, direct control and responsibility (Drucker 1993). Without such direct participation at the level of the workplace, without the so called "early diagnosis", it is impossible for the company to be successful in realising what Drucker calls "the theory of the business" (Drucker 1994).

The second important issue in connection with the basic concept of the PEMA is the danger of getting satisfied with the regulation this act comprises. The law has to provide merely a general framework; it has to be the general means for the realisation of the participation rights in the company. With such an umbrella act, only the minimum level of rights is set, anything more detailed and adjusted to concrete circumstances has to be a matter of negotiations between the employers and employees, various autonomous associations, the management, at individual and collective levels.

With regard to the connection between industrial and trade-union democracy it should be emphasised that the organised networks of trade union representatives 
have to struggle for the rights of employees in the companies and especially for a fair reward system. The trade unions have to negotiate for an improvement in working conditions and to represent the employees in disputes within the company or in the proceedings before arbitrators or courts. However, from the standpoint of the legislation on employee participation rights, it is not acceptable that the trade unions are holders of these rights. The participation rights belongs to employees as individuals, but their interests and rights may be represented by (trade-union) representatives. This should be valid at the company level, where the employees realise their right to participate in the decision making process and in supervision through their representatives, as well as at the level of their workplace, where the individual character of participation rights should be of special importance, although they can be also realised collectively within working groups.

However, it has to be emphasised that the link between industrial and tradeunion democracy is today challenged by the fact that trade unions in more highly developed countries (Italy, France, Great Britain, USA, Japan, Austria, Netherlands, Switzerland, Germany) are losing their power and membership (Kapstein 1996). In connection to this assertion, a study can be cited wich resulted in the conclusion that in American companies a higher level of rights is ascertained to the employees, if they are members of a trade union and this specific fact has the effect of a higher degree of productivity (Freeman, Medoff 1984). This is not unusual for the USA, where legal protection of employee rights is lower than in Western Europe and where more things fall under the negotiated power of employers and employees.

Generally speaking, it is reasonable to expect that the level of realisation and the protection of participation rights will be higher in Europe as well, if trade unions will negotiate for the employee rights, so that the individual will not stand alone in opposition to a company or an association of employers.

\subsection{Evaluation of the level of the protection for participation rights}

From the reports of the earlier mentioned institutions, which have worked in the field of the protection of human rights (during the period after the adoption of the new Constitution, the Law on Commercial Companies, the Participation of Employees in the Management Act and the Law on the Transformation of Company Ownership) the following facts become apparent.

The general evaluation is that the level of respect for human rights (in general) is similar to those in other countries of the Council of Europe. However, the lack of the real enforcement of employee rights which are (only) formally protected, continues to be a problem and has also resulted in the overburdening of the labour courts. The disregard of employee rights has to be understood in a sense that (most) managers do not have enough respect for the laws and collective agreements. They refuse to provide sufficient places on the supervisory board to 
employee representatives in the joint-stock companies or they try to prevent participation in the decision making of socially-owned capital. Furthermore, there are also frequent problems in relation to the late payment of wages and salaries, or the refusal by employers to pay compensation for illness (Social Attorney of Self-Management 1994, 1995).

On the other hand, I agree with the standpoint of those labour market experts, who reproach the Slovene legislation for having a too protective a role, especially regarding the generous insurance payments in cases of unemployment, the bountiful subvention of early retirement and high compensation used by companies to solve the problem of overemployment (Vodopivec 1995).

Perhaps, it is necessary to say that during this period there was no mention in political discussions of the importance of the realisation and protection of the rights of the industrial, economic and trade union democracy, and even less about their interdependency or indivisibility. These rights were not perceived as a measure for the legitimate or functional passing of the privatisation law and other legislation. Though there were clearly cases of illegal bankruptcy, which have in the most radical way led to concrete and massive violations of employee rights, this issue was ignored by the mass media. Instead all attention was, concentrated on the problem of fraudulent appropriation of socially-owned assets - which directors or executive officers were "stealing" socially-owned assets and how much of it was stolen? This is being used in political confrontations in order to convene extraordinary sessions of the parliament and in some other ways, the useless waste of energy.

\section{The status of the economic democracy}

So far, I have emphasised the interdependency and indivisibility of economic, industrial and trade union democracy. However, I have not mentioned the estimation that in general, legal regulations are the least modern and progressive (not only in Slovenia) in the field of economic democracy. This is the reason for giving special attention to economic democracy in the following chapter.

It is a fact that the system of private property in its commencement connects the basic participation rights in a company i.e., the right of management, control and profit-sharing, exclusively to (financial) capital. However, labour too, has gradually become a foundation for the right to participate in the decision making and supervision of business operations within the system of private property. This is not only a merit of the legislation on human rights and of the processes of democratisation in higher developed countries, but also one of the evolutionary changes in the field of management, looking for ways to be a more competitive company with higher productivity. It is a characteristic of the 
legislation of the European countries and the proposed legal documents of the European Union that today these rights are regulated by law.

Yet, the liberal doctrine does not allow the legal institutionalisation of the employee right to share ownership or profits in companies, which would actually mean that employees also take part in decision making processes about distribution of financial benefits. Instead, the right to share ownership and profit stays only with the financial capital. Nevertheless, the more highly developed world knows rather more wide-spread forms of economic democracy, for example: employee share ownership, internal buy-outs, profit-sharing, gain sharing, individual incentives plan, group incentives plan etc.

According to some estimation, in the USA with 10.8 million employee shareholders, $25 \%$ of big American corporations should by the end of the millennium have a substantial employee ownership plan (Owen 1995). By the end of the eighties $90 \%$ of Japanese companies, have listed their ESOP on the stock exchange including about $50 \%$ of all employees in these companies (Jones, Kato 1993). France, having among the states of the European Union the most developed economic democracy, had in 1991 about 17.000 valid contracts on various kinds of financial employee participation. In Germany financial participation was organised in approximately 5.000 companies. The Commission of the European Union has for some time emphasised the importance of employee participation in ownership of the company and views it as a mean to reach a more just distribution of wealth, a possibility to secure appropriate economic growth without the effects of inflation, to achieve employee motivation, and hence a higher productivity and a better competitive position in the market. However, the result of the work of the Commission is for now, a special proposition still in the phase of examination in the European Parliament and the Economic and Social Committee (Proposal for Council Recommendation concerning the promotion of employee participation in profits and enterprise results including equity participation 1991).

Nevertheless, economic democracy is still an issue for business decisions of company management wanting to prevent hostile take-over or seeing in an economic democracy stimulation for the employees to work better and for a more effective use of working time. Economic democracy is, therefore, negotiable but is far from being a part of the legislation on participation rights in companies.

Evidently the protectors of the liberal institutional system are neglecting the standpoint of the founders of liberalism, who based capitalism on the idea that an individual, who has contributed his labour to something productive, has the right to obtain the fruits of his work (Locke 1992). Through this postulate, the constitution of the so called conception of "self-ownership" is protected (Mill 1995), which is right at the basis of the liberal doctrine and human rights law. 
This rather philosophical position is not irrelevant because of the timely distance, but has to be explored within the modern challenges of the market economy. Namely, from the conclusions of Robert Solow, Nobel Prize winner for economics, we learn that the key factor for economic growth is technology, knowledge, innovation and not capital or the growth of labour force (Marshall 1989). His thesis had been proved by calculations and findings confirming that the level of productive use of knowledge is the factor determining the level of economic growth (Romer 1990; Pfeffer 1994; Becker et al. 1990). These findings are also accepted by sociologists talking about the economy of goods changing into a knowledge economy (Drucker 1993), with the intelligentsia becoming the largest class and the source of economic and social progress (Gouldner 1979). The consequence is that financial capital as a factor of production has become subordinate to intellectual capital (where the quality of social networks belongs ) and what was once called the labour as investment into the company, today means knowledge - the intellectual capital.

By exchanging the classic, repetitive, physical work with intellectual work, which has taken over the role of the main production factor, it becomes obvious that profit is created by labour (intellectual capital), as well as by financial capital.

Does the new legislation in Slovenia really mean a step towards the expansion, realisation and protection of the rights of economic democracy?

The Constitution, the Law on Commercial Companies and the Participation of Employees in the Management Act, which we have already discussed, do not mention the right of the employee to shareownership or profit-sharing (or the right to fair remuneration) within commercial companies.

At first sight, it seems that this great and important step will be taken by the LTCO, for it establishes the internal buy-out strategy as the most attractive option of privatisation. But this appearance is deceptive. The law grants the companies, having also been established by Constitutional Judge Krivic, a high degree of autonomy and brings them together in a legally regulated way in a position to look for appropriate owners (The Constitutional Court 1993, 127/II, separate opinion of Judge Krivic). It is true that the law has, through financial discounts and incentives, given an important advantage to the employees of companies, but the legal power of the LTCO is limited only within the transitional period. What will happen after the transformation is completed, is a completely open question.

If it really was the aim to maintain an ownership structure characterised by a significant part of employee ownership, then a number of additional regulations would be required.

It would be necessary, officially and at state level, to recognise the right of employees to shareownership or the right to share profit (and loss). An 
appropriate tax policy should be adopted, encouraging the employees to invest in their companies. The state should find appropriate solutions in the pension system and low taxation for the sale of these shares among employees (Blasi 1992). An appropriate way to attract banks into this project should be found, although banks are momentarily expecting rehabilitation and have a low creditworthiness. Appropriate legislation for the employee shares should be adopted and financial and legal experts to advise the managers of the employee funds should be given training. We would need independent institutions for the evaluation of employee shares, if these were not listed on the stock exchange. If we fail to grant a protective mechanisms against the massive sale of vouchers for money, when the trade on the open markets will be released, it will lead to a breakdown in the stock exchange.

An important achievement speaking in favour of economic democracy (a right to fair remuneration) in Slovenia are discussions between the representatives of the employers, the representative trade unions and the government. The result, for example, was the adoption of the Social Agreement for 1995 together with the agreement on the policy on wages and other incomes of the employees in commercial business. $^{7}$

In my conviction, this is a very important and welcome form of co-operation and legal regulation setting among other things the ratio between the highest and the lowest salary as $1: 15$. Here it is not the most important factor that Plato already taught Aristotle that within an organisation, the highest paid man should not get rewarded more than five times higher than the one with the lowest pay. For the time being, the findings that a very obvious inequality in incomes is negative for the economic growth are most relevant. T. Persson and G. Tabellini studied 56 countries and established a strong negative correlation between unequal incomes and the growth of the gross income per capita. The Institute for Public Policy Research found the same results published in Paying for Inequality. The USA and Switzerland having the biggest differences in incomes within their citizens had in the eighties, a significantly slower increase in productivity than more egalitarian countries like Japan, Germany, Sweden (The Economist 1994). Morton Deutsch established through forty years of study on the relationship between egalitarianism and productivity that small differences in salaries increase the cohesion between people and this stimulates an effective cooperation and increases productivity (Levine 1990).

7 It is mentioned in the Social Agreement that the Government of Slovenia will in 1995 propose legal solutions to regulate the participation of the employees and the management in the net profit of commercial companies (Social Agreemnet for the Year 1995). This promise was not fulfilled. However, a spacial law on the regulation of profit sharing in commercial companies is being drafted by the government in the year 1997. 
The connection between Plato's thesis and modern research may be found in the fact that it is (simply) unjust that the differences among the salaries are too extreme and that justice too, should be the basic regulatory principle within human rights law and not just the principles of freedom and equality.

\section{Conclusion}

Despite the fact that during the transitional period in Slovenia we have experienced, because of the LC, quite a drastic deterioration in industrial democracy, I could conclude that the present legislation, in the event that it will be supported by trade-unions, guarantees an appropriate model of industrial democracy and a sufficient level of protection of these rights. Trade-union democracy is well protected because the right to freedom of association is commonly accepted as the basic (liberal) right. However, the relation between trade-union and economic democracy seems to be more problematic. Trade unions have to struggle for the rights of the employees. If employees increase their share in the ownership structure of the company, it means that one person joins both sides i.e., of the worker and the owner. Parallel to this development, the protective function of trade unions becomes obsolete. However, are the trade union lobbies prepared to abolish themselves gradually? ${ }^{8}$

Within this paper I wanted to emphasise the strong connection between the contents of economic, industrial and trade-union democracy and I have given special attention to economic democracy which is, in my opinion, underdeveloped and not sufficiently protected. I have only come across one Slovenian publication that deals with the existence of a connection between economic, industrial and trade-union democracy. The title of the book is "Between Anti-Communism and Post-Socialism" (Rus 1992). Among the relevant actors responsible for running the state, I have found no echo of this book. Seen from the angle of promoting economic democracy the book The Slovene Company in the Future (Èibej et al. 1992) will probably have a more significant influence. Some authors from the Faculty of Economics in Ljubljana are suggesting (by explaining all positive and negative aspects) to the companies in Slovenia to choose one of the forms of profit-sharing and to include it into their organisational culture.

My major argument is that the rights of economic democracy should become part of the legislation on participation rights in companies. Not only because of functional needs such as the connection of the contents of trade union, economic and industrial democracy, micro- and macro-economic reasons, but above all because of justice. It is undoubtedly true that profit is made from financial, as

8 Here it is worth mentioning that in the USA 10.8 million employees are included in the ESOP, but they are not members of any trade union (Blasi, Kruse 1990). 
well as from intellectual capital. The legalisation of economic democracy would establish a more balanced relation between labour and capital. A stronger connection between these two elements of industrial civilisation would establish a better link between freedom and responsibility and a possibility for the social emancipation of a wider population. Without economic democracy it is also impossible to talk about the principle of democratic order, which has been included into Article 1. of the Slovene Constitution. The democratic principle of the social system demands a certain distribution of power and wealth. Consequently the democratic principle is not established by merely having a party system with a parliamentary structure, free elections and non imperative mandate of the elected representatives in the parliament. There is no democracy without the active and functional participation of individuals in making decisions at all levels, from the micro-regulation of the working environment in commercial and non-commercial organisations, through participation in local and public issues, up to (active) citizenship at the national level.

In my opinion, the institutionalisation of participation rights of economic democracy is a necessary tool (but not a sufficient one) for realising the concept of development proposed by the United Nations in the Declaration on the Right to Development (1986). ${ }^{9}$

From the point of view of justice, such a concept of development implicitly suggests that a legal system of human rights should not only protect civil and political rights and thus reward only those who are the most talented, advantaged and have the most luck. The concept of human rights must also include the protection of autonomous agents from risks which are out of their control. The concept of human rights should therefore be based on the integrity of human personality, needs, abilities and risks, such as: ignorance, disability, accidents, disease, poverty, unemployment, criminality, etc., because they are constant factors in our life and do by all means affect social, economic and cultural rights as well.

It seems that this idea of social justice, which had already been advocated at the very beginning of modern sociology (Durkheim 1957) and developed further by J. Rawls (1971), has not been overlooked in the constitutional concept of human rights in Slovenia, since this concept is based on the triple principles of equality, freedom and justice (welfare state). However, speaking only with respect to the legal transformation of companies in Slovenia, if the legislature doesl not protect the participation rights of economic democracy as a basic human right, this will only prove the thesis that the process of transition and, in particular,

9 "The right to development is an inalienable human right by virtue of which every human person and all peoples are entitled to participate in, contribute to, and enjoy economic, social and political development, in which all human rights and fundamental freedoms can be fully realized” (Declaration on the Right to Development 1986: Art. 1) 
privatisation in Central and Eastern Europe has depended mostly on political feasibility (Boycko et al., 1994). Some emphasis has also been placed on expectations for the improvement of economic effectiveness, whereas justice has been left aside.

\section{References}

Amended proposal for a Fifth Directive founded on Article 54 (3) (g) of the EEC, (1983), in: Official Journal of European Communities, COM, No, C 240/2.

Becker, G. et al, (1990): Human Capital Fertility and Economic Growth, Journal of Political Economy, Vol. 98, No, 5, pp 12-37.

Blasi, J./ Kruse, D. (1990): The New Owners, Harper \& Business.

Blasi, J. (1992): Employee Ownership is not Socialism, Gospodarski vestnik, 4. 6. 1992, Ljubljana, No. 22, pp 22-23.

Boycko, M. (1994): Voucher Privatisation, Journal of Financial Economics, Vol. 35, 249-266.

Convention for the Protection of Human Rights and Fundamental Freedoms, (1995): Secretariat to the European Commission of Human Rights, Council of Europe, Strasbourg.

Council for the Protection of Human Rights and Fundamental Freedoms, (1991): Annual Report, in: Report of the National Assembly of the Republic of Slovenia, No. 27, pp 14-19.

Council for the Protection of Human Rights and Fundamental Freedoms, (1992): Annual Report, in: Report of the National Assembly of the Republic of Slovenia, No. 2, pp 4754.

Council for the Protection of Human Rights and Fundamental Freedoms, (1993a): Memorandum, in: Report of the National Assembly of the Republic of Slovenia, No. 2 pp 54-56.

Council for the Protection of Human Rights and Fundamental Freedoms, (1993b), Annual Report, in: Report of the national Assembly of the Republic of Slovenia, No. 13, pp 92-95.

Èibej, J. et al. (1992): The Slovene Company in the Future, Cisef, Faculty of Economics, Ljubljana,

Declaration on the Right to Development, (1986): in: Yearbook of the United Nations, Department of Public Information, New York, 40, pp 717-721.

Drucker, P. (1993): The Postcapitalist Society, Butterworth - Heinemann.

Drucker, P. (1994): The Theory of the Business, Harvard Business Review, September/October, pp 95-104.

Durkheim, Emile, (1957): The Professional Ethics and Civic Morals, Routledge and Kegan Paul, London.

Freeman, R./ Medoff, J. (1984): What do Unions do? Basic Books, New York,.

Gouldner, A. (1979): The Future of Intelectuals and the Rise of New Class, Oxford University Press, Oxford. 
International Covenant on Civil and Political Rights, (1988): in: A Compilation of International Instruments, United Nations, New York, pp 18-38.

International Covenant on Economic, Social and Cultural Rights, (1988): in: A Compilation of International Instruments, United Nations, New York, pp 7-12.

Jones, D./ Kato, T. (1993): Employee Stock Ownership Plans and Productivity in Japanese Manufacturing Firms, British Journal of Industrial Relations, Vol. 31, No. 3, pp 331346.

Kapstein, B. E. (1996): Workers and the World Economy, Foreign Affairs, May-June, pp 1637.

Künnemann, R. (1995): A Coherent Approach to Human Rights, Human Rights Quarterly, Vol. 17, No. 2, pp 323-342.

Labour Court, (1993): Report on the Problems of Juridical Protection of the Rights from Labour Relations, in: Report of the National Assembly of the Republic of Slovenia, No. 2, pp 56-63.

Lasso, J. A. (1994/ 1995): Defining the Mandate, Harvard International Review, XVII, No. 1, Winter, pp 38-41.

Law on Commercial Companies, (1993): Official Gazette of the Republic of Slovenia, 30/93.

Law on Companies, (1989): Official Gazette of the Socialist Federal Republic of Yugoslavia, $77 / 88$.

Law on Social Capital, (1989): Official Gazette of the Socialist Federal Republic of Yugoslavia, 84/89.

Law on Transformation of Company Ownership, (1992): Official Gazette of the Republic of Slovenia, 55/92.

Levine, D. (1990): Participation, Productivity and the Firm's Environment, California Management Review, Vol. 32, No. 4, pp 86-100.

Locke, J. (1992): The Second Treatise of Government, Cambridge University Press, Cambridge.

Marshall, E. (1989): Robert Solow: Nobel Prize Winner for Economics, Pregled Embassy of the United States of America, Belgrade, No. 245, pp 8-9.

Mill, J. S. (1995): Principles of Political Economy, Intelex.

Owen, G. (1995): Employee Ownership in Polaroid Corporation, Employee Ownership seminar, 29. 3. - 30. 3. 1995, Bled - Slovenia.

Participation of Employees in the Management Act, (1993): Official Gazette of the Republic of Slovenia, 42/93.

Pfeffer, J. (1994): Competitive Advantage Through People, California Management Review, Vol. 36, No. 2, 9-28.

Proposal for a Council Directive complementing the Statute for a European Company with regard to the involvement of employees in the European Company, (1989), Bulletin of the European Communities, 5. 
Proposal for a Council Recommendation concerning the promotion of employee participation in profits and enterprise results including equity participation, (1991), Commission of the European Communities, COM, 259, Brussels.

Rawls, J. (1971): The Theory of Justice, Harvard University Press, Cambridge, Massachusetts.

Romer, P. (1990): Endogenous Technological Change, Journal of Political Economy, II, No. 5, 71-102.

Rus, V. (1992): Between Anti-Communism and Post-Socialism, Faculty of Social Sciences, Teorija in Praksa, Ljubljana.

Social Agreement for the Year 1995, (1995): Official Gazette of the Republic of Slovenia, 22/95.

Social Attorney of Self-Management, (1992): Bulletin, Ljubljana, No. 73.

Social Attorney of Self-Management, (1993): Report of the Social Attorney on the Positions and Problems from the Field of Protection of Socially-Owned Capital and Protection of the Employees Rights, in: Report of the National Assembly of the Republic of Slovenia, No. 2, pp 33-38.

Social Attorney of Self-Management, (1994): Report of the Social Attorney of SelfManagement on the Position and Problems from the Field of Protection of SociallyOwned Capital and Protection of the Employees Rights, in: Report of the National Assembly of the Republic of Slovenia, No. 13, pp 96-102.

Social Attorney of Self-Management, (1995): Report of the Social Attorney of SelfManagement on the Positions and Problems from the Field of Protection of Socially Owned Capital and the Protection of the Employees Rights, in: Report of the National Assembly of the Republic of Slovenia, No. 9, pp 60-67.

Sudre, F. (1990): La premiere décision "quart monde” de la Commission européene des droits de l'homme: Une "bavure" dans une jurisprudence dynamique, Revue universelle des droits de l'homme, 2, No. 10, pp 349-353.

The Commission for Constitutional Questions, (1991): The Proposal for the Constitution, in: Report of the National Assembly of the Republic of Slovenia, No. 30, pp 2-20.

The Constitutional Court, (1992): Decisions and Reports, 23/I, pp 54-58; 35/I, pp 86-95; 39/I, pp 102-104; 56/I, 134-136, Nova revija, Ljubljana.

The Constitutional Court, (1993): Decisions and Reports, 18/II, pp 41-45; 52/II, pp 127-135; 117/II, pp 357-373; 121/II, pp 390-398; 127/II, pp 413-416, Nova revija, Ljubljana.

The Constitutional Court, (1994): Decisions and Reports, 38/III, pp 179-186; 39/III, pp 187190; 50/III, 220-223; 85/III, pp 368-372; 86/III, 372-376; 99/III, pp 470-476, Nova revija, Ljubljana.

The Constitutional Court, (1995): Decisions and Reports, 42/IV, Vol. 1, pp 222-234; 147/IV, Vol. 2, pp 566-569, Nova revija, Ljubljana.

The Constitution of the Republic of Slovenia, (1991): Official Gazette of the Republic of Slovenia, 33/91-I.

The Economist, (1994): For Richer, for Poorer, November 5th - 11th, pp 19-21. 
The European Social Charter, (1992): Council of Europe, The Directorate of Human Rights, Strasbourg.

Universal Declaration of Human Rights, (1988): in: A Compilation of International Instruments, United Nations, New York, pp 1-7.

Vienna Declaration, (1993): Council of Europe Summit, Vienna, 9. Oct. 1993.

Vodopivec, P. (1995): Elements of the Strategy for Labour Market Development, in: Rus, V. (ed.), Slovenia after the Year 1995, Faculty of Social Sciences, Ljubljana, pp 281-297. 